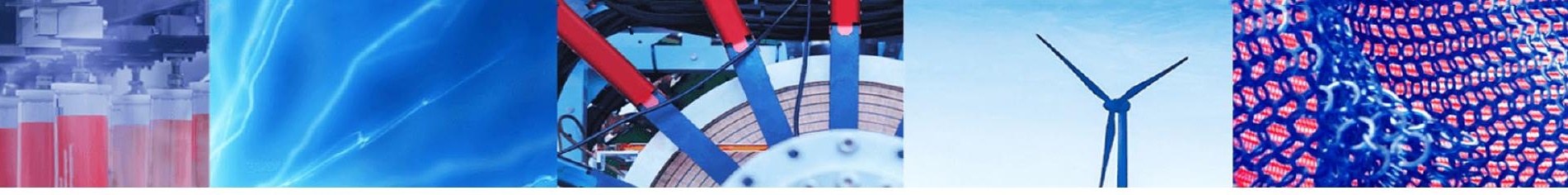

Case Study

\title{
E-waste it wisely: lessons from Africa
}

\author{
Thomas Maes $^{1}$ [D . Fiona Preston-Whyte ${ }^{1}$
}

Received: 13 September 2021 / Accepted: 19 January 2022

Published online: 05 February 2022

(c) The Author(s) 2022 OPEN

\begin{abstract}
E-waste is the world's fastest growing and most valuable domestic waste stream. The increasing production of e-waste is driving elevated levels of export from developed to developing countries. Although countries worldwide are actively recognising the issues around e-waste and introducing policies, legislation or regulations governing e-waste, a large fraction of e-waste, goes undocumented at its end-of-life. Much of the global e-waste is accumulating in open dumpsites in several African countries. Using available data, we calculate the total e-waste in Africa (locally produced plus imported e-waste) for 2019 to be between 5.8 and 3.4 metric tonnes (Mt). This is believed to be an underestimate, large data gaps exist, hindering more precise estimates. The data is further complicated by, sometimes intentional, differences in labelling and reporting between formal and intermittent informal importers. Based on the available data, the main African recipients of e-waste are Nigeria, Ghana, and Tanzania, with Kenya, Senegal and Egypt featuring as countries of concern. The lack of proper waste management in the recipient developing countries, leads to environmental contamination and human exposure. A coordinated, regional and global, approach is needed in tackling e-waste. Regulatory frameworks, together with monitoring and compliance mechanisms need to be developed, financed, and enforced.
\end{abstract}

Keywords E-waste $\cdot$ Africa $\cdot$ EEE $\cdot$ WEEE $\cdot$ Basel Convention · Bamako Convention

\section{Introduction}

The increase in mismanaged waste has been reported around the world, made visible by plastic pollution. Global waste production continues to grow with increasing population and increasing per capita consumption associated with economic growth [1]. With increasing economic and technological development, dependence and rapid obsolescence of electronics increased [2, 3]. This makes e-waste the world's fastest-growing domestic waste stream [4]. Global volumes have doubled in the last decade [5]. Containing rare-earth and other metals, it is also one of the most valuable waste streams per volume. Overall, the value of selected raw materials contained in e-waste in 2019 was equal to $\$ 57$ billion USD, corresponding to a total of $25 \mathrm{Mt}$ [4]. In addition to existing predicted increases of e-waste [6] and despite the economic impact of the pandemic, global e-waste may increase rapidly during and post COVID-19, driven by demands for electronics due to remote working and home schooling [7].

\subsection{E-waste: definition and types}

Though legal definitions are still being agreed, E-waste, is a term used to cover all waste items of electrical and electronic equipment (EEE) and their parts (Fig. 1) [8]. Items which are intentionally discarded, without the intent of reuse, are also called Waste EEE (WEEE). Used EEE on the other hand is second hand-meant to be functional but includes non-functional, but repairable items.

Thomas Maes, thomas.maes@grida.no| 'TRID-Arendal, Teaterplassen 3, 4836 Arendal, Norway.

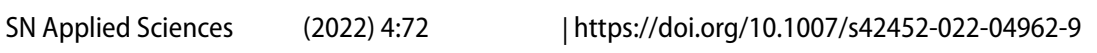


E-waste Production and recycling rate by continent (2019)

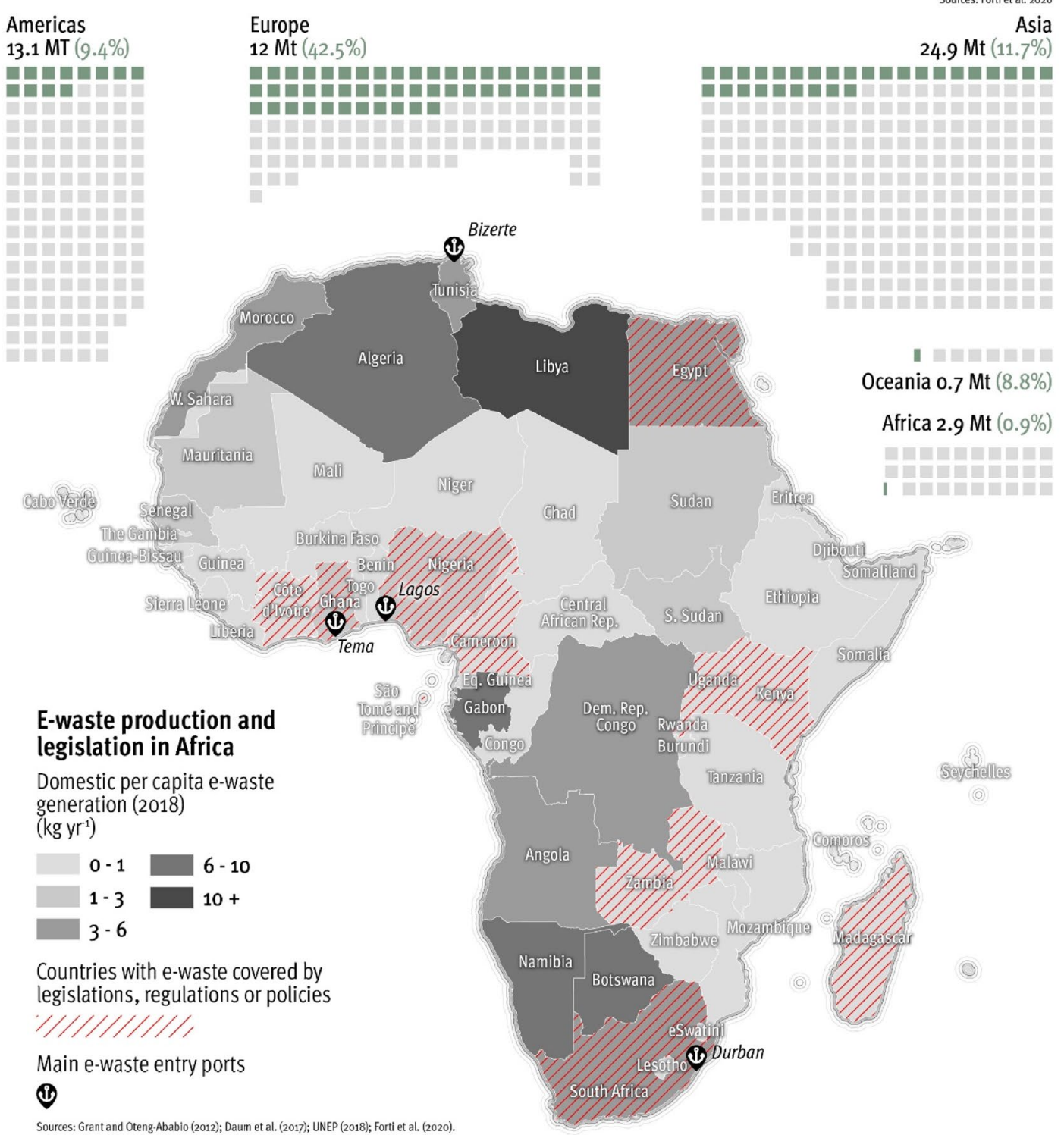

GRID-Arendal (2021)

Global e-waste production (Million tonnes)

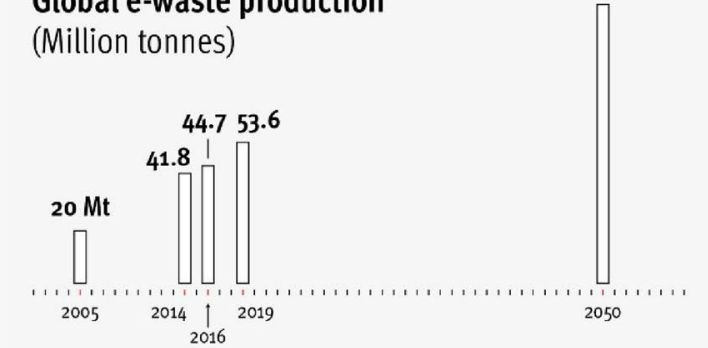

Sources: Bastiaan et al. (2010); Balde et al. (2017); Asante et al. (2019); Parajuly et al. (2019); Forti et al. (2020).
$>106$

2020).

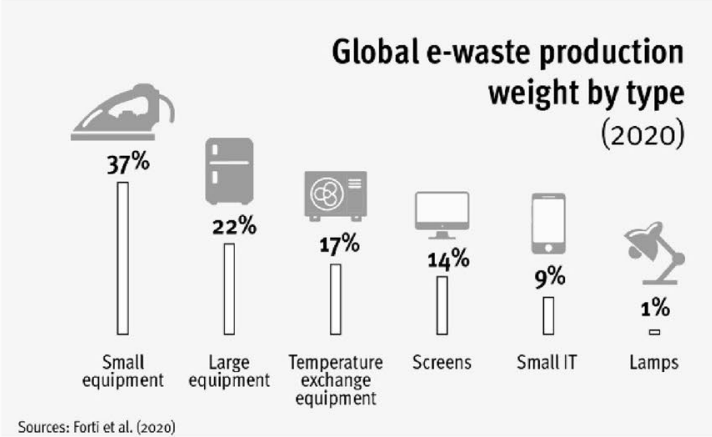

Fig. 1 The African e-waste perspective 


\subsection{E-waste: global production of e-waste}

In 2016, 8.9 Mt of e-waste was documented to be collected and recycled globally, corresponding to $20 \%$ of e-waste generated that year (44.7 Mt) [9]. This decreased to $17.4 \%$ of 53.6 Mt in 2019. Over 5 years (2014-2019), e-Waste volumes grew by $21 \%$, and the 2014 volumes are predicted to double by 2030 [4]. The discrepancies in volumes produced and percentage properly collected and recycled (Fig. 1), indicates that a large fraction goes undocumented and is untreated and/or illegally transported and leaking [4].

\subsection{E-waste: regulatory frameworks and legislative drivers}

Countries worldwide are actively recognising the issues around e-waste and introducing domestic policies, legislation or regulations governing e-waste. In 2014, just 44\% of the world's inhabitants were protected by legal waste related frameworks, this increased to $66 \%$ in 2017 and $71 \%$ with 78 countries by October 2019 [4]. In Africa, the two conventions regulating e-waste are the Basel Convention and Bamako Convention.

Global regulatory frameworks such as the Basel Convention (1992) directly deals with e-waste as a hazardous waste. The Basel Convention on the "Control of Transboundary Movements of Hazardous Wastes and Their Disposal" is a multilateral treaty focussed on reducing environmental and human health risks resulting from hazardous waste trading. In 2019, changes were made to Annexes II, VIII and IX of the Basel Convention (during the 14th Conference of the Parties). These amendments aim to improve the control of hazardous plastic waste movements across country boundaries. Amongst others, it requires written notification and approval for such movement across boundaries. Exemptions are made for EEE intended for reuse, thus reducing hazardous waste formation and extending the life of EEE. However, discussions within the Basel Convention on the differentiation between waste or "intended for reuse" are ongoing [4].

To help achieve the objectives of the Basel Convention (article 11), the convention encourages parties to organise regional, multilateral and/or bilateral agreements on hazardous waste, which-resulted in the Bamako Convention (1998). This is a treaty consisting of African countries forbidding the import of any hazardous waste, with the aim of reducing and managing e-waste transport nationally and across African states. In theory, this ensures disposal of electronics in accordance with clean and green environmental principles [3].

Though not always effective, legislation exists to prevent hazardous waste trade in countries exporting waste to developing countries. Challenges arise due to slow regulatory progress and low levels of legislative enforcement [4]. In Europe, this issue is regulated by the Waste Shipment Regulation (2006), which includes provisions to address uncontrolled and illegal waste exports, and the EU Waste Framework Directive (2008). The last one was recently revised to modernise and streamline its provisions, to focus on inspections and includes waste management principles such as the "polluter pays principle" or the "waste hierarchy".

\subsection{E-waste end-of-life options and leakages}

Monitoring global quantity and streams of e-waste is difficult, no harmonised end-of-life measurement methods exist for all countries [10]. A large fraction of e-waste, $82.6 \%$ or $44.3 \mathrm{Mt}$ in 2019 , goes undocumented at its endof-life [4]. The increasing production of e-waste is driving elevated levels of export from developed to developing countries [11]. Owing to the lack of appropriate waste management in the recipient developing countries, including open burning of residual unrepairable fractions, this leads to local contamination, human exposure, and crop contamination [11]. The majority of these exports are illegal or disguised as being intended for reuse or as scrap or even worse, described as charitable donations [3]. Though measuring the exact volume of the global flow of e-waste is difficult, it is widely accepted that the volume is significant, with transboundary movement of e-waste and used EEE accounting for $7-20 \%$ of e-waste generated [4]. A large part of the global e-waste is accumulating in open dumpsites in several African counties, notably Ghana and Nigeria [2].

To quantify "leakage" - a term used for illegally exporting waste, the Basel Secretariat receives member states reports on illegal waste trades. From 2015 to 2017, the Basel Action Network (BAN) put 314 trackers on electronic waste items sent to recycling facilities across ten European Union (EU) countries. The data indicated that $6 \%$ of traced items (19) were exported from country of origin. Over half of those items (11) were destined for developing countries, making these exports "highly likely to be illegal" [12]. The other 8 exported trackers were found in other EU member states. The non-EU destination countries included Nigeria, Ghana, Tanzania, Hong Kong, Pakistan, and Thailand. In total $64 \%$ of the discovered exports, that left the EU, were taken to Africa (7 items). The United Kingdom (UK) was the country responsible for shipping the most electronics outside the EU to less developed nations, with 5 tracked items. BAN [12] estimates that a total of $352,474 \mathrm{Mt}$ of e-waste is exported from EU countries to developing nations every year. It is likely that the exports to Africa have increased as a result of the Chinese National Sword Policy, 2017. The 
transboundary European export rate (6\%) falls far below the United States of America (USA) export rate of 40\% [12]. The USA is the only industrialised country not to ratify the Basel convention nor its amendments and has insufficient laws controlling e-waste exports [3].

\section{Transboundary movement of e-waste to Africa}

\subsection{Estimated volumes and hotspots}

Even though monitoring the transboundary movement of e-waste into Africa is notoriously difficult, three African countries, two on the West coast, Ghana, and Nigeria, and one on the East coast, Tanzania, have been identified as recipients of e-waste from the EU/UK [11-13]. Other recipient countries within Africa have also received e-waste from developed countries [5, 11, 14]. Import data for e-waste is currently lacking for the Americas and Asia, however, one can assume many other port cities in Africa are similarly receiving large volumes of the same types of discarded European consumer products [12] as well as from the USA and other developed nations [15]. Two West African countries, Ghana and Nigeria have high direct imports of e-waste, with Nigeria the leading importer of used EEE on the African continent [11, 14]. Approximately $60,000-71,000 \mathrm{t}$ of used EEE were imported annually into Nigeria through the two main ports in Lagos in 2015 and 2016 [16]. In Nigeria, 77\% of used EEE imported during this period originated from the EU $[9,11]$. Additionally, three of Africa's most active ports: Durban (South Africa), Bizerte (Tunisia), and Lagos (Nigeria) have all been identified as the major ports of entry of used EEE to the African continent [17]. This indicates that, shipments containing hazardous materials still circumvent the Basel and Bamako Conventions by passing through busy environments, illegally, through methods such as mislabelling [18].

\subsection{Production of e-waste in Africa}

Globally, per-capita e-waste generation rates vary geographically [11]. The e-waste generation in Africa, with an average annual per capita e-waste generation of $2.5 \mathrm{~kg}$, is well below Europe $(16.2 \mathrm{~kg})$ and the Americas $(13.3 \mathrm{~kg})[4,9]$. Africa locally generates between 50 and $85 \%$ of its total e-waste, the remainder originating from illegal transboundary imports from developed countries in the Americas, Europe, and China [15]. About 2.9 Mt of e-waste was generated in Africa in 2019, with the highest e-waste generating countries, also being major population centres [19], identified as Egypt, South Africa and Nigeria [4]. Though considering $\mathrm{kg}$ per capita per year generation, Libya $\left(10+\mathrm{kg} \mathrm{capita}^{-1}\right.$ year $\left.^{-1}\right)$ is the highest per capita generator, followed by Algeria, Botswana, Gabon, Namibia (6-10 kg capita ${ }^{-1}$ year $^{-1}$ ) [11]. Using the above figures from SBC [15] and Forti et al. [4], we calculate the total e-waste in Africa (locally produced plus imported e-waste) for 2019 to be between 5.8 Mt and 3.4 Mt. Based on the data gaps presented by others and in this review, we consider this to be an underestimation.

\subsection{Quality of imports into Africa}

In addition to the locally generated waste, Africa must process imported transboundary e-waste. This importation of e-waste can have the unintended consequence of displacing these developing economies' capacity to recycle their own domestic waste [20]. A lot of this e-waste is introduced as "charitable donations" and "second-hand goods" $[3,18]$, the implication being that these goods are functional. Workshop data from Accra, Ghana in 2019, showed that out of $0.215 \mathrm{Mt}$ of e-waste imported: $30 \%$ was not waste, but "new" products (unused stocks), 14\% was second-hand-possible to repair or keep using, leaving $56 \%$ as actual waste needing processing [21]. The exact numbers vary between studies $[15,16,22]$, but all show e-waste $(30 \%, 15 \%$ and $19 \%$ respectively) imported into Ghana as usable EEE. The data is further complicated by differences between formal and intermittent informal importers, with Grant and Oteng-Ababio [17] reporting a decrease in working condition from 70 to $60 \%$ between shipment types into Nigeria.

\subsection{End-of-life options}

Globally, EEE end-of-life options include reuse, repair, refurbishing, repurposing of parts into other products, recycling and resource recovery, landfill (both controlled disposal and sanitary engineered landfilling), incineration uncontrolled and indiscriminate dumping and littering. Within Africa, most of these options are utilised-dictated by infrastructure, markets, and value items.

With built in obsolescence [2,3], reuse, repair and refurbishing of used EEE is not the primary option globally. The lifetime of used EEE imported into Africa is often extended through informal repair. However, with many imported used EEE close to their end of life, the shortened lifespan eventually increases the amount of e-waste within Africa [23]. For products that cannot be fixed, disassembly occurs. Leading to the reuse of parts in other, different, EEE or goods [2]. 
Recycling rates of e-waste vary across the continent and are difficult to compare due to different interpretations. South Africa recycles $9.7 \%$ of its generated e-waste, in that it is dismantled and the valuable fractions exported for recycling (beneficiation) [24]. While Ghana rather processes $40-60 \%$ of its domestically generated e-waste of which $95 \%$ is done by the informal sector [23]. The difference between both being that the informal sector typically doesn't "recycle" - they collect for recycling, they repair for reuse, but they don't beneficiate which would require expensive pyrometallurgical or hydrometallurgical facilities. Recycling complexity varies across the continent, with South Africa, Egypt, Morocco, Namibia, and Rwanda having some formal recycling e-waste industry (supported by the informal industry) $[4,24,25]$. While the industry in Ghana and Nigeria is solely driven by the informal sector. In long term treatment sites, such as Agbogbloshie (Ghana), informal recycling of e-waste has been vertically integrated into a functional e-waste economy [26-29].

Formal industrial incineration of waste does not occur in Africa, with the exception of one facility, Reppie WtE, in Ethiopia. Most recognised landfills are uncontrolled, nor sanitary engineered [11]. Resource recovery, or "urban mining" is widespread in the informal handling of e-waste in Africa [11], although it is alleviating the depletion of natural resources, the unregulated manner in which it takes place is an extremely polluting process [5]. The e-waste which is not reabsorbed into the markets through the above processes accumulates in illegal dumpsites, is openly burnt, or littered in the African environment.

\section{E-waste impact in Africa}

\subsection{Environmental impacts}

The toxic and cancerous pollutants released into the environment during improper treatment of e-waste at end-oflife (Fig. 2), include heavy metals such as lead, cadmium, and mercury, as well as dioxins, furans, and polycyclic aromatic hydrocarbons [12]. Within Africa, close to e-waste processing sites, toxic elements, persistent organic pollutants (POPs), and heavy metals have been observed in elevated levels in dust, soils [30-33] and vegetation, including edible plants [34, 35]. Further environmental effects have been observed because of higher metal and rare earth element (REEs) [36] concentrations in downstream aquatic and marine environments, causing adverse marine consequences including smaller, sicker, and sparser fish stocks [37, 38]. REEs are contaminants of emerging concern [36]. Heavy metals, organic pollutants, and higher concentrations of Polychlorinated Biphenyls (PCBs) [39] have been found in aquatic environments, as well as polycyclic aromatic hydrocarbons (PAHs), oxygenated PAHs, trace metals and metalloids in fish samples [37]. These compounds can be linked to e-waste processing [39, 40] and are toxic to several aquatic species [40].

On average, electronics consist for $17 \%$ of plastics, mostly high-quality recyclable polymers like HDPE, although they often contain hazardous compounds, e.g. flame retardants, which make them difficult to recycle. In South Africa remanufacturing of WEEE plastics is mostly $(80 \%-7500 \mathrm{t})$ exported [41], this is likely to be similar in other African countries. The remaining plastic fractions are in the best case landfilled, but more likely to be unrecovered, dispersed into the environment in a range of sizes due to fragmentation resulting from informal recycling processes. Furthermore, depending on landfill characteristics, recent surveys have indicated that larger plastics fragment and landfill leachates may act as another source of microplastics. Microplastics discharged from these sites may pose greater risks to human and environmental health by sorbed toxic and persistent hazardous chemicals [42].

Current e-waste processing in Africa has the potential to impact the ozone layer and climate change. Open burning, not only releases toxins but also carbon dioxide $\left(\mathrm{CO}_{2}\right)$. The importation of old cooling devices, such as refrigerators or air-conditioning units', and the improper and unsafe disposal of these devices' leads to the release of ozone depleting substances (ODS) and greenhouse gasses (GHG) $[4,43]$. Additionally, the inefficiency of these items during use undermines Africa's climate efforts through energy inefficiency [44]. In contrast, "urban mining" contributes to an uncaptured amount of metal resource recovery.

\subsection{Human health}

The rudimentary processing of the e-waste in informal sites through manual removal, open burning and open acid digestion leads to widespread contamination [5]. The toxins released into the environment bioaccumulate in human tissues [44-48], and have been found, along with PAHs $[46,49,50]$ in e-waste workers $[46-48,51]$ and surrounding populations $[29,52]$. These toxins lead to several adverse health effects (Fig. 2), including carcinogenic, non-carcinogenic [53], mutagenic [54,55], genotoxic [35], neurotoxicity and endocrine disruption [56] and neonatal issues [3]. Further health issues, specifically to e-waste workers, include physical injuries, chest and respiratory tract associated symptoms, malaria, headaches, body pains and stomach discomfort [51]. 
Impacts of e-waste processing in Africa - e-waste contains some of the most harmful toxins known to the environment

\begin{tabular}{|c|c|c|c|}
\hline Importing & Recirculating & Dismantling & Open burning and discarding \\
\hline Increase in GDP & Reuse, Repair, Refurbish, Recycle & Income for informal workers & Health risk for informal workers, \\
\hline $\begin{array}{l}\text { Extend life of electronics, } \\
\text { but shorter life span in Africa }\end{array}$ & $\begin{array}{l}\text { Increase Entrepreneurship } \\
\text { opportunities }\end{array}$ & $\begin{array}{l}\text { Health risk for informal workers, } \\
\text { population and the environment }\end{array}$ & $\begin{array}{l}\text { population and the environment } \\
\text { Loss of resources }\end{array}$ \\
\hline Increase access to electronics & $\begin{array}{l}\text { Income for informal workers } \\
\text { Loss of discarded resources }\end{array}$ & - Loss of discarded resources & \\
\hline
\end{tabular}

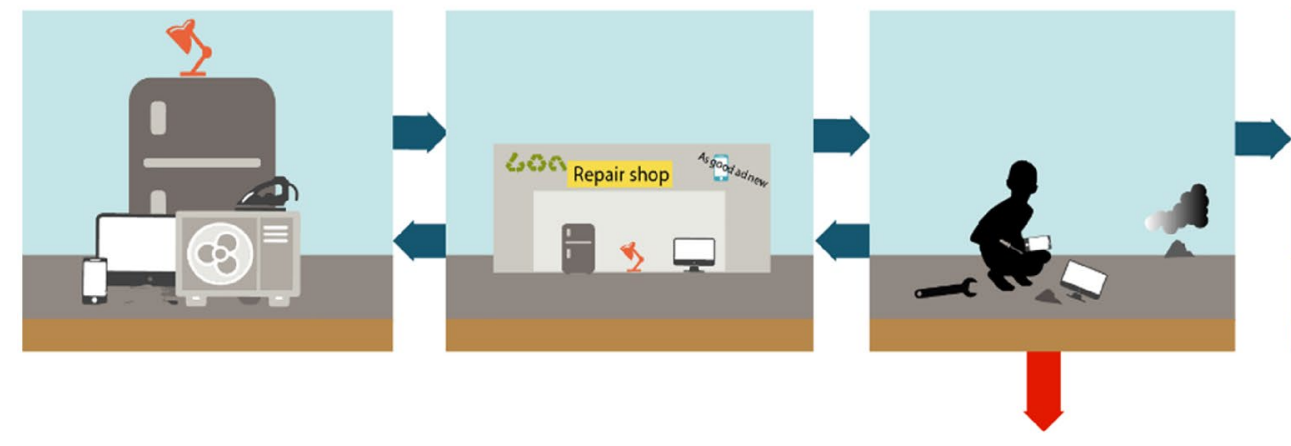

Toxins are dissolved into the air - transported and precipitated in the vicinity of the burning site
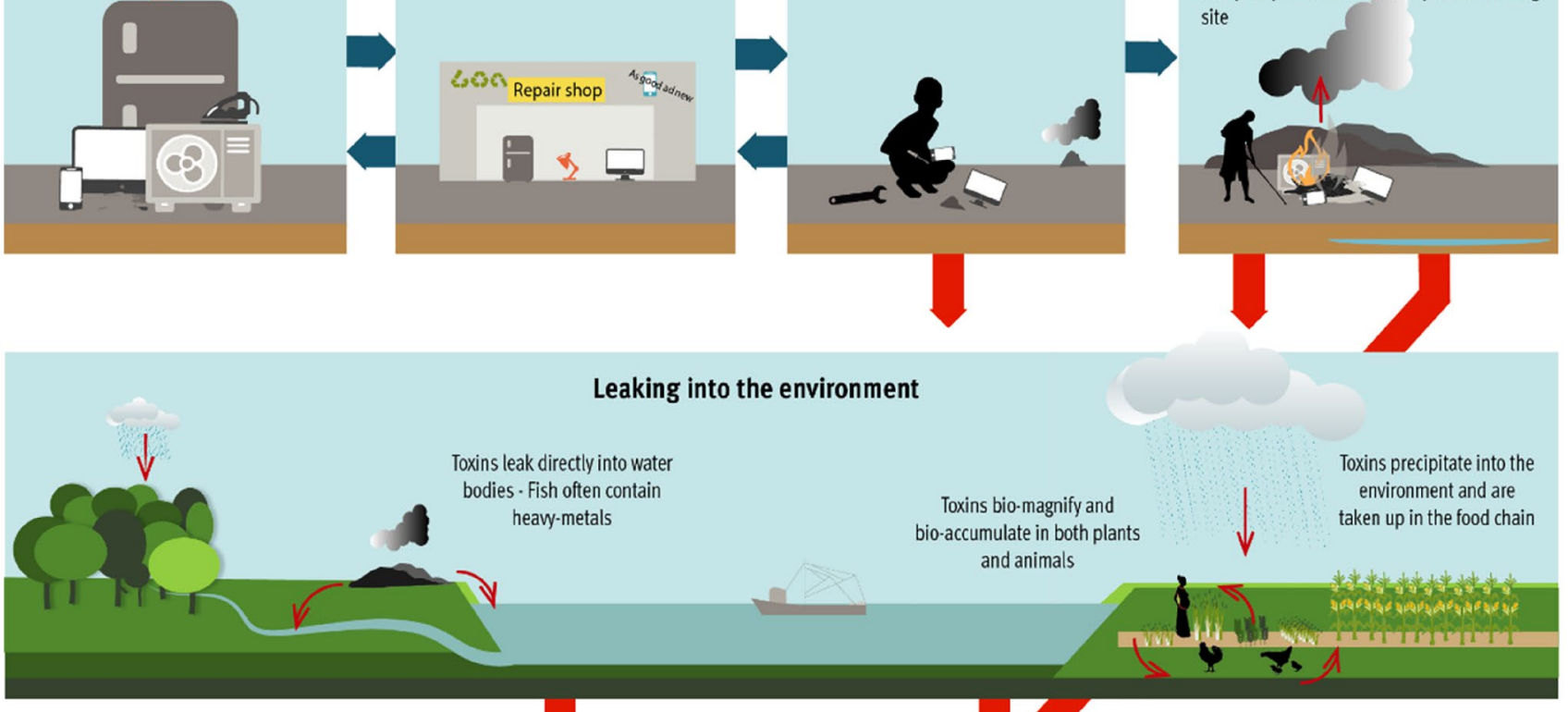

Toxins leak directly into water bodies - Fish often contain heaw-metals bio-accumulate in both plants and animals

Toxins precipitate into the environment and are taken up in the food chain
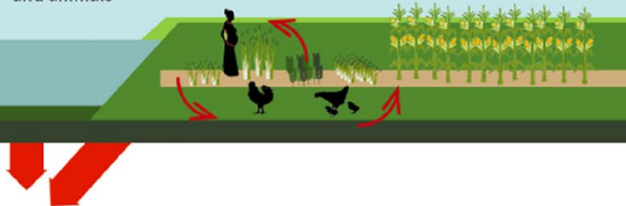

Chemicals affecting the Human body and its systems

E-waste workers and vulnerable people (children, old people, pregnant women) are disproportionately affected

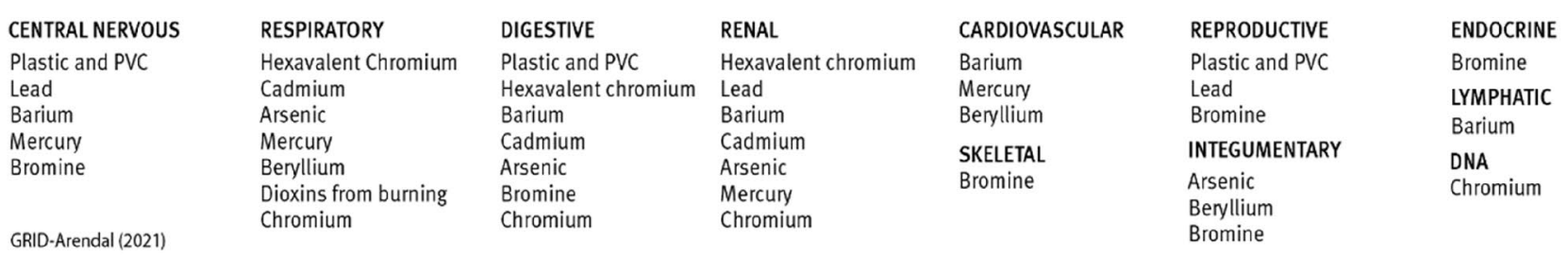

Fig. 2 Impacts of e-waste processing in Africa

\subsection{Economic impacts and societal impacts}

The transport of used EEE and e-waste to Africa, has resulted in an informal, yet important industry, with far reaching consequences. Used $\mathrm{EEE}$, and repairable $\mathrm{EEE}$, have permitted individuals and companies to buy inexpensive and vital electronics or IT equipment [2], helping socioeconomic development [11, 57]. Informal e-waste recycling provides a major source of livelihood for many poor urban communities [29]. The informal sector contributes to $25 \%$ of the e-waste recycling in South Africa, with an estimated workforce of 10,000 with 2000 regular workers in 2013 [58]. Within Ghana, in 2014, e-waste activities generated US\$105-268 million, creating employment for at least 200,000 people nationwide [23]. Agbogbloshie, described as the biggest e-waste site in sub-Saharan Africa [51], creates 4000-6000 direct jobs [59], supporting strong entrepreneurship and economic opportunities through the development of community-based collection, recovery, and recycling businesses [2].

$\mathrm{E}$-waste in Africa is ambivalent in its nature. The rudimentary processing of the informal sector creates elevated risk for health and environment alike [5], affecting the entire surrounding population and ecosystem. Such pollution and health effects will have long term environmental, social and economic consequences. 
Inversely, e-waste processing allows for entrepreneurship, job creation, reuse, and refurbishment for sale of cheap electronics, less waste and recapturing of metals [2]. Globally, as Extended Producer Responsibility (EPR) schemes develop, the cost of end-of-life and recycling will become built into the cost of EEE. This increase in costs will have societal effects, increasing the technological gaps already present in our world [3]. Bridging these gaps is too often used to justify the environmental racism present in the current transboundary movement of e-waste [60].

\section{Discussion}

\subsection{Future projections}

Prior to 2012, Nigeria and China received the majority of the global cross-border transport of e-waste [35], this changed in 2011 when China introduced the Regulation on Management of the Recycling and Disposal of Waste Electrical and Electronic Equipment [61]. Over the past decade, illegal e-waste transport to African countries, such as Egypt, Ghana, Kenya, Nigeria, Senegal and Tanzania, received attention in the international news [11]. The growing global manufacture of electronics, in combination with the absence of action plans in African countries and the lack of infrastructure for proper and sustainable e-waste management [2], has led to e-waste becoming a growing African problem, with global origins. Global forecasted scenarios for e-waste generation show an increase of more than $100 \%$ in the next 30 years [6]. The use of EEE in Africa is low but growing at a staggering pace $[11,15]$, for example, the e-waste in Senegal, Uganda and South Africa is projected to increase by a factor of two to eight in the next 10 years [62], and e-waste inflows into Ghana were projected to double in three years between 2017 and 2020 [22], however no new data is available to verify these projections.

\subsection{Lessons learned and further considerations}

Transboundary movement of e-waste is dynamic, reacting to social, economic, and regulatory changes [4]. A coordinated, regional and global, approach is needed in tackling e-waste. Given the flow of e-waste to Africa, the Basel Convention is lacking in practical enforcement. Given the flow of e-waste within the continent, highlighted by the import of e-waste to Agbogbloshie, Ghana through South Africa, Tunisia, and Nigeria [18], enforcement of the Bamako Convention can also be improved.

E-waste, when treated as a waste to be discarded leads to the loss of valuable metals and REEs contained within.
Modest recycling rates of metals combined with rising demand for high-tech goods containing them, require increased mining with its associated social, environmental, health, energy, water, and carbon-footprint costs [63]. Mining and metallurgical processes produce significant amounts of waste and constitute one of the biggest challenges to the environment [64]. Additionally, a positive correlation between mining and conflict on a local level has been detected-the historical rise in mineral prices might explain up to $1 / 4$ of the average level of violence across conflict African countries over the same period. The effect of mining on communities, notably its catalytic and shifting effects on relocation and urban development, are important drivers of urbanisation in Africa [65].

Rigorous international environmental directives, including UNEP goals aimed at improved recycling of WEEE [66], the restriction of the use of hazardous substances in $\mathrm{EEE}$ [67], and EPR [68] programmes all have made recycling an important responsibility. Environmental pressures and climate change are leading to companies and supply chains considering new models for environmental protection. The "Circular Economy" (CE) model was established as a sustainable approach, able of dissociating economic development from material utilization and waste production [69]. Greener options aim to apply WEEE waste to turn it into simple, available and viable polymetallic secondary REE supplies. To secure a stable and more environmentally friendly supply, attention has turned towards "urban mining". Consistent with the CE approaches of the 4R scheme (Reduce, Reuse, Remanufacture and Recycle), the "urban mining" method offers several advantages, leading to improved energy efficiency and lower demand for mining of new raw materials [70], and so lowering the mining footprint. In a near future, by unlocking the potential that WEEE provides as a material, proper and efficient WEEE recycling will become a very important sector from economic and environmental perspectives.

The absence of e-waste infrastructure and e-waste legislation are some of the challenges facing e-waste management in Africa [11, 71]. Africa is the worst covered continent regarding e-waste legislation [5]. However, the legal landscape of Africa is changing rapidly, with the number of African countries covered by e-waste legislation, policy or regulation rising from 3 in 2018 [11] to 13 in 2020 [4]. Subregional approaches are also occurring within the East Africa community, adopting a regional e-waste strategy [72], and an enforcement programme to monitor and control transboundary movements of used EEE customised for Benin, Egypt, Ghana, Nigeria, and Tunisia. A scheme for exchanging information on used EEE between exporting and importing states was also developed [11, 14].

Policy or regulatory frameworks need reachable targets and effective enforcement [4]. For enforcement, 
timely response and finance is key [3]. Enforcement of conventions lacks funding in Africa. Given the rising environmental and health cost of e-waste in Africa, this commodity should become an enforcement priority. Waste related funding should be orientated towards incentive programmes constructing recycling infrastructure and in country technology across Africa. Currently, CE in the WEEE industry has been addressed mainly in Europe and Asia [69]. In the absence of a full CE, there are few options for financing WEEE management globally and in Africa. Funding of convention implementation for the processing of e-waste comes in four forms: public financing, private financing, public-private partnerships, and donors and grants.

Public financing is a common practice in Asia, this involves the funding of WEEE management services by the government through budget provision [73]. This practice proves difficult in Africa. Existing reasons for the poor management of waste in Africa, include, amongst others, feeble organisational structures; lack of suitable skills; insufficient funds; weak regulation; lack of enforcement; low public awareness; corruption, conflict; political instability; and absence of political will [74].

Private financing involves private sector funding of WEEE management services and running of the provision formally or informally. In Africa, the informal e-waste sector dominates the entire WEEE chain from collection to extraction. Regardless of the creations in WEEE "recycling" businesses, a major gap is that tackling the issue demands integrated multi-actor interventions with multiple stakeholders to reduce WEEE imports, while improving safe and efficient recycling capacity.

Public-private partnerships (PPP) merge the government and private sector in supplying resources and management skills for WEEE services [75]. Public-private partnerships with results-based-financing offers opportunities for WEEE management in Africa as it allows for innovation and locally appropriate solutions while focusing on agreed WEEE targets.

The last option is to rely on the use of donors and grants. This can be combined with a PPP to cater for a specific WEEE management aspect. Several international conventions or agreements recognise, the need for a financial mechanism to fund and assist developing country Parties with respect to both mitigation and adaptation in continuation of their existing obligations under these conventions. The potential of WEEE recycling in terms of a country's greenhouse gas (GHG) reduction target would offer a new path towards climate-change mitigation [76]. The call for financial assistance from Parties with more financial resources to those that are less endowed and more vulnerable by the United Nations Framework Convention on Climate Change (UNFCCC), the Kyoto Protocol and the Paris Agreement might be useful in the financing of WEEE management. The Global Environment Facility (GEF) funds are available to developing countries and transition economies to achieve the goals of the international environmental conventions and agreements. GEF assistance is given to government agencies, civil society organizations, private sector companies, research institutions, among the broad diversity of potential partners, to carry out projects and programs in recipient countries.

It is important to note that African countries have varying GDP's, population figures, centres and social systems, and associated income and cost streams. As such, no single financial model will be suitable for all countries, but rather a mixture of the above. The informal sector is important in e-waste management in Africa. The informal nature of the e-waste processing industry ensures that the social injustices faced by the workers and surrounding marginalised communities [77], go beyond the issue of e-waste [77]. As the most vulnerable workers, often migrant [3, 77, 78], gravitate to the work. To prevent the industry moving further into the shadows, legal development and enforcement needs to take a supportive approach [51]. Countries should engage with informal waste collectors, protecting the informal workers with adequate personal protection and making sure e-waste is collected and sent to licenced recyclers for efficient and safe processing [79].

Sustainable funding such as through EPR schemes, supportive legislation, stakeholder partnerships, and inclusion of the existing informal and formal sectors are needed to increase the recycling capacity and decrease the amount of WEEE contaminating the environment and endangering human health. Charges for EEE sold by producers should be added by classifying EEE according to their eventual end-of-life treatment requirements and cost. As such improved design would be financially rewarded, allocate costs of historic waste proportionately (on the basis of tonnes of new products sold), and provide sufficient financial guarantees against future waste costs and liabilities [80]. Furthermore, in line with the Paris Agreement, as part of a global effort, developed country Parties should "continue to take the lead in mobilizing climate finance from a wide variety of sources, instruments and channels, noting the significant role of public funds, through a variety of actions, including supporting country-driven strategies, and taking into account the needs and priorities of developing country Parties" (UNFCCC 2015).

\subsection{Recommendations}

To achieve a comprehensive implementation regime globally and regionally, a rigorous enforcement of the Basel [5] and Bamako Conventions is needed while 
encouraging outlying states to ratify the conventions. However, this would not solve the current loopholes, nor the lack of enforcement allowing for the illegal transboundary movement $[3,11,15]$. Regulatory frameworks, together with monitoring and compliance mechanisms need to be developed and financed.

E-waste processing in Africa is driven by poverty, unemployment, and socioeconomic needs in Africa [11], as well as public and private sector design globally. The e-waste treatment technologies available globally are not necessarily appropriate, nor economically viable in Africa. Valuable and appropriate innovations, appropriate for Africa are arising within Africa-and African centric solutions should be supported and developed. There is a need to create efficient, effective, and clean "urban mining" systems in Africa [11], combined with an aim to recuperate materials from e-waste, processing them within Africa (so that resources, especially metals, are not exported out of Africa for value increased processing elsewhere) thus, preserving resources, controlling pollution while creating jobs and wealth for Africa.

Africa is set to undergo a major social and economic transformation over the next century as its population explodes, cities urbanise and consumer purchasing habits change [11]. This will lead to an increase in locally generated e-waste-as well as the increasing global e-waste and associated imports. Creating robust data on generation and movement of e-waste will help both the private and public sector in planning, financing, and developing healthy e-waste processing that combines the existing informal industry and their expertise into the formal green economy. Proper assessments on pilot projects are needed and this knowledge needs to be shared [3]. Developing the policies and legal frameworks now, for collection and processing, considering planning and financial instruments, will be hugely beneficial for the African public and private sectors to design e-waste processing in Africa that meets environmental standards and supports a thriving industry.

Globally, change is needed too. Countries exporting used EEE to Africa (or elsewhere) need to ensure that their second-hand exports are working prior to export or can be easily fixed and are not damaged in transport. In other words, that the used EEE is not e-waste. Additionally, design change to facilitate repairability, reuse and recycling of e-waste is an imperative, including but not limited too; modularity, reduction, and ultimate removal of substances of very high concern (SVHC), clear ingredients, minimum standards for recycled content. Lastly, EPR plays an important part in both creating a circular economy product and financing collection and end of life options.
Acknowledgements The work described in this paper was produced with financial support from the Norwegian Agency for Development Cooperation (NORAD), Ministry of Foreign Affairs. The authors thank Kristina Thygesen and Levi Westerveld for the graphic design. The authors would like to thank leva Rucevska and Clever Mafuta for their comments on an earlier draft of this paper and for the reviewers for their comprehensive comments.

Funding Funding was provided by Norwegian Agency for Development Cooperation (NORAD).

\section{Declarations}

Conflict of interest There is no potential conflicting or competing interest that are directly or indirectly related to the work submitted for publication, nor any financial nor non-financial interests to disclose. The research did not involve human participants and/or animals. We have obtained informed consent from all authors.

Open Access This article is licensed under a Creative Commons Attribution 4.0 International License, which permits use, sharing, adaptation, distribution and reproduction in any medium or format, as long as you give appropriate credit to the original author(s) and the source, provide a link to the Creative Commons licence, and indicate if changes were made. The images or other third party material in this article are included in the article's Creative Commons licence, unless indicated otherwise in a credit line to the material. If material is not included in the article's Creative Commons licence and your intended use is not permitted by statutory regulation or exceeds the permitted use, you will need to obtain permission directly from the copyright holder. To view a copy of this licence, visit http://creativecommons. org/licenses/by/4.0/.

\section{References}

1. Jambeck JR, Geyer R, Wilcox C, Siegler TR, Perryman M, Andrady A, Narayan R, Law KL (2015) Plastic waste inputs from land into the ocean. Science 347:768-771

2. Asante KA, Amoyaw-Osei Y, Agusa T (2019) E-waste recycling in Africa: risks and opportunities. Curr Opin Green Sustain Chem 18:109-117. https://doi.org/10.1016/j.cogsc.2019.04.001

3. Daum K, Stoler J, Grant RJ (2017) Toward a more sustainable trajectory for e-waste policy: a review of a decade of e-waste research in Accra. Ghana. Int J Environ Res Public Health. https:// doi.org/10.3390/ijerph14020135

4. Forti V, Balde CP, Kuehr R, Bel G (2020) The Global E-waste Monitor - 2020: Quantities, flows and the circular economy potential. United Nations University (UNU)/United Nations Institute for Training and Research (UNITAR) - co-hosted SCYCLE Programme, International Telecommunication Union (ITU) \& International Solid Waste Association (ISWA). Bonn/Geneva/ Rotterdam

5. Mihai F-C, Gnoni M-G, Meidiana C, Ezeah C, Elia V (2019) Chapter 1 - Waste Electrical and Electronic Equipment (WEEE): Flows, Quantities, and Management-A Global Scenario. In: Electronic Waste Management and Treatment Technology. Prasad MNV, Vithanage M (eds) Elsevier Science \& Technology Books, pp 1-34. https://doi.org/10.1016/B978-0-12-816190-6.00001-7

6. Parajuly K, Kuehr R, Awasthi AK, Fitzpatrick C, Lepawsky J, Smith E, Widmer R, Zeng X (2019) Future e-waste scenarios. The StEP Initiative, UNU ViE-SCYCLE, and UNEP IETC. 
7. Probst C, Lukas S, Huwer J (2020) COVID19: distance learning in times of crisis digital technologies and resources for learning under lockdown promoting homeschooling in chemistry education with augmented reality. In: ICERI2020 proceedings, pp 2023-2031

8. Step Initiative (2014) One global definition of e-waste. ISSN: 2071-3576

9. Baldé CP, Forti V, Gray V, Kuehr R, Stegmann P (2017) The Global E-waste Monitor-2017. United Nations University (UNU), International Telecommunication Union (ITU) \& International Solid Waste Association (ISWA). Bonn/Geneva/Vienna

10. Baldé CP, Wang F, Kuehr R, Huisman J (2015) The Global E-waste Monitor-2014. United Nations University, IAS - SCYCLE. Bonn, Germany

11. UNEP (2018) Africa Waste Management Outlook. Nairobi, Kenya

12. BAN (2018) Holes in the circular economy: WEEE leakage from Europe. A report of the e-trash transparency project. Seattle

13. Magashi A, Schluep M (2011) e-waste assessment Tanzania. UNIDO e-waste Initiative, Tanzania

14. Schluep M, Terekhova T, Manhart A, Müller E, Rochat D, Osibanjo $\mathrm{O}$ (2012) Where are WEEE in Africa? In: Electronics goes green 2012+(EGG). Fraunhofer Verlag (eds). IEEE. pp 1-6. Stuttgart

15. SBC (2011) Where are WEee in Africa? Findings from the Basel Convention E-waste Africa Programme

16. Odeyingbo O, Nnorom IC, Deubzer O (2017) Person in the Port Project: assessing import of used electrical and electronic equipment into Nigeria. UNU-ViE SCYCLE and BCCC Africa, Bonn

17. Grant R, Oteng-Ababio M (2016) The global transformation of materials and the emergence of informal "Urban Mining" in Accra. Ghana Afr Today 62:2-20

18. Grant R, Oteng-Ababio M (2012) Mapping the invisible and real "African" economy: urban e-waste circuitry. Urban Geogr 33:1-21

19. UNDESA (2019) World population prospects 2019

20. Velis CA (2015) Circular economy and global secondary material supply chains. Waste Manag Res 33:389-391. https://doi.org/10. 1177/0734242X15587641

21. Abidjan Convention and GRID-Arendal (2020) Preventing and managing Marine Litter in West, Central and Southern Africaworkshop proceedings.

22. Amoyaw-Osei Y, AgekumO, Pwamang J, Mueller E, Fasko R, Schluep M (2011) Ghana e-waste country assessment. Green Advocacy Ghana \& Empa Switzerland. Accra, Ghana

23. Oteng-Ababio M, Amankwaa EF (2014) The e-waste conundrum: balancing evidence from the North and on-the ground developing countries realities for improved management. Afr Rev Econ Financ 6:181-204

24. Department of Environmental Affairs (2018) South Africa State of Waste. A report on the state of the environment. First draft report. Pretoria, South Africa

25. Barba-Gutierrez Y, Adenso-Diaz B, Hopp M (2008) An analysis of some environmental consequences of European electrical and electronic waste regulation. Resour Conserv Recycl 152:481-495

26. Amankwaa EF (2014) E-waste livelihoods, blood lead level and sediment pollution in Ghana. LAP Lambert Academic Publishing

27. Amankwaa EF (2014) E-waste livelihoods, environment and health risks: unpacking the connections in Ghana. West Afr J Appl Ecol 22:1-15

28. Amankwaa EF (2013) Livelihoods in risk: exploring health and environmental implications of e-waste recycling as a livlihood strategy in Ghana. J Mod Afr Stud. https://doi.org/10.1017/ S0022278X1300058X

29. Amankwaa EF, Tsikudo Adovor KA, Bowman JA (2017) "Away" is a place: the impact of electronic waste recycling on blood lead levels in Ghana. Sci Total Environ 1(601-602):1566-1574. https:// doi.org/10.1016/j.scitotenv.2017.05.283
30. Atiemo SM, Ofosu FG, Aboh IJK (2012) Assessing the heavy metals contamination of surface dust from waste electrical and electronic equipment (e-wste) recycling site in Accra. Ghana Res J Environ Earth Sci 4:605-611

31. Brigden K, Labunska I, Santillo D, Johnston P (2008) Chemical contamination at e-waste recycling and disposal sites in Accra and Kofordua, Ghana. Greenpeace Research Laboratories Technical Note 10/2008, August 2008, pp 24. Amsterdam

32. Kyere VN, Greve K, Atiemo SM (2016) Spatial assessment of soil contamination by heavy metals from informal electronic waste recycling in Agbogbloshie, Ghana. Environ Health Toxicol 31:110. https://doi.org/10.5620/eht.e2016006

33. Tue NM, Goto A, Takahashi S, Itai T, Asante KA, Kunisue T, Tanabe $S$ (2016) Release of chlorinated, brominated and mixed halogenated dioxin-related compounds to soils from open burning of e-waste in Agbogbloshie (Accra, Ghana). J Hazard Mater 302:151-157

34. Affum AO, Osae SD, Kwaansa-Ansah EE, Miyittah MK (2020) Quality assessment and potential health risk of heavy metals in leafy and non-leafy vegetables irrigated with groundwater and municipal-waste-dominated stream in the Western Region, Ghana. Heliyon 6:e05829. https://doi.org/10.1016/j.heliyon. 2020.e05829

35. Alabi OA, Bakare AA, Xu X, Li B, Zhang Y, Huo X (2012) Comparative evaluation of environmental contamination and DNA damage induced by electronic-waste in Nigeria and China. Sci Total Environ 423:62-72. https://doi.org/10.1016/j.scitotenv.2012.01. 056

36. Gwenzi W, Mangori L, Danha C, Chaukura N, Dunjana N, Sanganyado E (2018) Sources, behaviour, and environmental and human health risks of high-technology rare earth elements as emerging contaminants. Sci Total Environ 636:299-313. https:// doi.org/10.1016/j.scitotenv.2018.04.235

37. Bandowe BAM, Bigalke M, Boamah L, Nyarko E, Saalia FK, Wilcke W (2014) Polycyclic aromatic compounds (PAHs and oxygenated PAHs) and trace metals in fish species from Ghana (West Africa): bioaccumulation and health risk assessment. Environ Int 65:135-146

38. Boadi KO, Kuitunen M (2002) Urban waste pollution in the Korle Lagoon, Accra, Ghana. Environmentalist 22:301-309

39. Hosoda J, Ofosu-Anim J, Sabi EB, Akita LG, Onwona-Agyeman S, Yamashita R, Takada H (2014) Monitoring of organic micropollutants in Ghana by combination of pellet watch with sediment analysis: e-waste as a source of PCBs. Mar Pollut Bull 86:575-581

40. Huang J, Nkrumah PN, Anim DO, Mensah E (2014) E-waste disposal effects on the aquatic environment: Accra. Ghana Rev Environ Contam Toxicol 229:19-34

41. Mintek (2017) Mapping South Africa's waste electrical and electronic equipment (WEEE) dismantling, pre-processing and processing technology landscape. Johannesburg

42. Silva ALP, Prata JC, Duarte AC, Soares AMV, Barceló D, RochaSantos T (2021) Microplastics in landfill leachates: the need for reconnaissance studies and remediation technologies. Case Stud Chem Environ Eng. https://doi.org/10.1016/j.cscee.2020. 100072

43. GIZ (2020) Management and destruction of existing ozone depleting substances in ODS banks [WWW Document]. URL https://www.giz.de/en/worldwide/30797.html. Accessed 29 March 2021

44. Fleming P (2020) A flood of polluting air conditioners hampers Africa's Climate Efforts [WWW Document]. Yale Environ. 360. URL https://e360.yale.edu/features/a-flood-of-pollutingair-conditioners-hampers-africas-climate-efforts. Accessed 29 March 2021 
45. Adriano DC (2003) Trace elements in terrestrial environments: biogeochemistry, bioavailability and risks of metals, 2nd edn. Springer, New York

46. Asante KA, Agusa T, Biney CA, Agyekum WA, Bello M, Otsuka M, Itai T, Takahashi S, Tanabe S (2012) Multi-trace element levels and arsenic speciation in urine of e-waste recycling workers from Agbogbloshie, Accra in Ghana. Sci Total Environ 424:63-73

47. Srigboh RK, Basu N, Stephens J, Saampon E, Perkins M, Neitzel RI, Fobil J (2016) Multiple elemental exposures amongst workers at the agbogbloshie electronic waste (e-waste) site in Ghana. Chemosphere 164:68-74

48. Wittsiepe J, Fobil JN, Till H, Burchard GD, Wilhelm M, Feldt T (2015) Levels of polychlorinated dibenzo-p-dioxins, dibenzofurans (PCDD/Fs) and biphenyls (PCBs) in blood of informal e-waste recycling workers from Agbogbloshie, Ghana and controls. Environ Int 79:65-73

49. Caravanos J, Clarke EE, Osei CS, Amoyaw-Osei Y (2013) Exploratory health assessment of chemical exposures at e-waste recycling and scrapyard facility in Ghana. J Health Pollut 3:11-22

50. Feldt T, Fobil JN, Wittsiepe J, Wilhelm M, Till H, Zoufaly A, Burchard G, Göen T (2014) High levels of PAH-metabolites in urine of e-waste recycling workers from Agbogbloshie, Ghana. Sci Total Environ 466-467:369-376. https://doi.org/10.1016/j.scito tenv.2013.06.097

51. Asampong E, Dwuma-Badu K, Stephens J, Srigboh R, Neitzel R, Basu N, Fobil J (2015) Health seeking behaviours among electronic waste workers in Ghana. BMC Public Health 15(1):1065. https://doi.org/10.1186/s12889-015-2376-z

52. Asamoah A, Essumang DK, Muff J, Kucheryavskiy SV, Søgaard EG (2018) Assessment of PCBs and exposure risk to infants in breast milk of primiparae and multiparae mothers in an electronic waste hot spot and non-hot spot areas in Ghana. Sci Total Environ 612:1473-1479. https://doi.org/10.1016/j.scitotenv. 2017.08.177

53. Ackah M (2019) Soil elemental concentrations, geoaccumulation index, non-carcinogenic and carcinogenic risks in functional areas of an informal e-waste recycling area in Accra, Ghana. Chemosphere 235:908-917. https://doi.org/10.1016/j.chemo sphere.2019.07.014

54. Alabi OA, Bakare AA (2011) Genotoxicity and mutagenicity of electronic waste leachates using animal bioassays. Toxicol Environ Chem 93:1073-1088

55. Lui Q, Cao J, Li K, Miao XH, Li G, Fan FY, Zhao YC (2009) Chromosomal aberrations and DNA damage in human populations exposed to the processing of electronics waste. Environ Sci Pollut Res 16:329-338. https://doi.org/10.1007/s11356-008-0087-z

56. Costa LG, Giordano G (2007) Developmental neurotoxicology of polybrominated diphenyl ether (PBDE) flame retardants. Neurotoxicology 28:1047-1067

57. Osibanjo O, Nnorom IC (2007) The challenge of electronic waste (e-waste) management in developing countries. Waste Manag Res 25:489-501. https://doi.org/10.1177/0734242X07082028

58. e-Waste Association of South Africa (2013) Business oppurtunities in South Africa's e-waste sector

59. Prakash S, Manhart A (2010) Socio-economic assessment and feasibility study on sustainable e-waste management in Ghana. Öko-Institut e.V. Freiburg, Germany

60. Okafor-Yarwood I, Adewumi IJ (2020) Toxic waste dumping in the Global South as a form of environmental racism: evidence from the Gulf of Guinea. Afr Stud 79:285-304. https://doi.org/ 10.1080/00020184.2020.1827947

61. Wong NWM (2018) Electronic waste governance under "one country, two systems": Hong Kong and Mainland China. Int J Environ Res Public Health. https://doi.org/10.3390/ijerph1511 2347
62. Bello IA, Bin Ismail MN, Kabbashi N (2016) Solid waste management in Africa: a review. Int J Waste Resour 6:1-4. https://doi. org/10.4172/2252-5211.1000216

63. Izatt RM, Izatt SR, Bruening RL, Izatt NE, Moyer BA (2014) Challanges to achievement of metal sustainability in our high-tech society. Chem Soc Rev 43, 2451-2475. https://doi.org/10.1039/ C3CS60440C

64. Matinde, E., Simate, G.S., Ndlovu, S., 2018. Mining and metallurgical wastes: A review of recycling and re-use practices. J South African Inst Min Metall 118:825-844. https://doi.org/10.17159/ 2411-9717/2018/v118n8a5

65. Berman N, Couttenier M, Rohner D, Thoenig M (2017) This mine is mine! How minerals fuel conflicts in Africa. Am Econ Rev 107:1564-1610. https://doi.org/10.1257/aer.20150774

66. Shittu OS, Williams ID, Shaw PJ (2021) Global E-waste management: Can WEEE make a difference? A review of e-waste trends, legislation, contemporary issues and future challenges. Waste Manag 120:549-563. https://doi.org/10.1016/j.wasman.2020.10. 016

67. Koh SC, Gunasekaran A, Tseng CS (2012) Cross-tier ripple and indirect effects of directives WEEE and RoHS on greening a supply chain. Int J Prod Econ 140:305-317. https://doi.org/10. 1016/j.ijpe.2011.05.008

68. Lodhia S, Martin N, Rice J (2017) Extended producer responsibility for waste televisions and computers: a regulatory evaluation of the Australian experience. J Clean Prod 164:927-938. https:// doi.org/10.1016/j.jclepro.2017.07.020

69. Bressanelli G, Saccani N, Pigosso DC, Perona M (2020) Circular Economy in the WEEE industry: a systematic literature review and a research agenda. Sustain Prod Consum 23:174-188. https://doi.org/10.1016/j.spc.2020.05.007

70. Kaya M (2016) Recovery of metals and nonmetals from electronic waste by physical and chemical recycling processes. Waste Manag 57:64-90. https://doi.org/10.1016/j.wasman.2016. 08.004

71. Dittke S, Newson G, Kane C, Hieronymi K, Schluep M (2008) A material recovery facility in Cape Town, South Africa, as a replicable concept for sustainable ewaste management and recycling in developing countries. In: Global symposium on recycling, waste treatment and clean technology, Cancun

72. EACO (2013) Model framework for e-waste management

73. Zhang D, Cao Y, Wang Y, Ding G (2020) Operational effectiveness of funding for waste electrical and electronic equipment disposal in China: an analysis based on game theory. Resour Conserv Recycl 152. https://doi.org/10.1016/j.resconrec.2019. 104514

74. Godfrey L, Ahmed MT, Gebremedhin KG, Katima JH, Oelofse S, Osibanjo O, Richter UH, Yonli AH (2019) Solid waste management in africa: governance failure or development opportunity ? Reg Dev Afr. https://doi.org/10.5772/intechopen.86974

75. Deubzer O (2011) E-waste management in Germany. Bonn, Germany

76. Menikpura SNM, Santo A, Hotta Y(2014) Assessing the climate co-benefits from waste electrical and electronic equipment (WEEE) recycling in Japan. J Clean Prod 74:183-190. https:// doi.org/10.1016/j.jclepro.2014.03.040

77. Akese GA, Little PC (2018) Electronic waste and the environmental justice challenge in Agbogbloshie. Enviorn Justice. https:// doi.org/10.1089/env.2017.0039

78. Cassels S, Jenness SM, Biney AAE, Ampofo WK, Nii-Amoo Dodoo F (2014) Migration, sexual networks, and HIV in Agbogbloshie. Ghana Demogr Res 31:861-888. https://doi.org/10.4054/DemRes.2014.31.28

79. Baldé $C P$, lattoni $G$, Luda $V$, Nnorom I, Pecheniuk $O$, Kuehr $R$ (2021) Regional e-waste monitor for the CIS + Georgia - 2021. Bonn, Germany 
80. Mayers K, Lifset R, Bodenhoefer K, Van Wassenhove LN (2012) Implementing individual producer responsibility for waste electrical and electronic equipment through improved financing. J Ind Ecol 17:186-198. https://doi.org/10.1111/j.1530-9290.2012. 00528.x

Publisher's Note Springer Nature remains neutral with regard to jurisdictional claims in published maps and institutional affiliations.

\section{SN Applied Sciences}

A SPRINGER NATURE journal 